\title{
Computational Analysis of Single Nucleotide polymorphisms (SNPs) in Human T- Cell Acute Lymphocytic Leukemia Protein 1 (TAL1) Gene/ Comprehensive Study
}

\author{
Shaza W. Shantier ${ }^{1 *}$, Hashim E. Elmansi², Mihad E. Elnnewery ${ }^{3}$, Hind K. Osman ${ }^{2}$, Isam-Aldin A. \\ Alhassan', Fatima A. Abdelrhman²,Ahmed A. Yagaub², Einas M. Yousif ${ }^{2}$, Alaa I. Abdalla ${ }^{2}$, \\ Rawan A. Elamin², Howina S. Fadol², Afra A. Fadl Alla², Mohamed A. Hassan² \\ ${ }^{1}$ Faculty of Pharmacy, University of Khartoum, Sudan \\ ${ }^{2}$ Department of Biotechnology, Africa City of Technology, Khartoum, Sudan \\ ${ }^{3}$ Department of Clinical Chemistry, Omdurman Islamic University, Sudan \\ *Corresponding Author: sshantier@yahoo.com
}

\begin{abstract}
Background: TAL1 is a proto-oncogene whose distorted modifications in committed T-cell Precursors is related with the development of T-ALL, it also found to be related to many other human hematological diseases such as lymphoblastic lymphoma, immunodeficiency 18, acute myeloid leukemia and diamond-blackfan Anemia. Objectives: This study aims to predict the effect of nsSNPs on TAL1 protein structure function Methods: Retrieved nSNPs in the coding and 3'UTR regions were analyzed using different in silico tools. Interactions of TAL1 with functionally similar genes were investigated using Genemania. Post-translational modifications in several sites of the protein were also investigated. Results: Out of ninety nsSNPs identified, only eight were found damaging to protein function of which one is located in the basis helix-loop-helix domain (bHLH). Two SNPs were anticipated by PolymiRTs to prompt disturbance or creation of miR binding sites. Conclusion: The present study is the first ever computational analysis of TAL1's nsSNPs hence this effort might be of help in the near future for inventing early diagnostic and therapeutic measures for T-ALL
\end{abstract}

Keywords: Acute lymphoblastic leukemia, TAL1, Computational analysis, Basic helix-loop-helix; Domain 


\section{Introduction}

Acute lymphoblastic leukemia (ALL) is a malignant disease of the bone marrow in which hematopoietic stem cells (HSC), which are called lymphoid cells in this case, are arrested and transformed in an early stage [1,2]. ALL accounts for $26 \%$ of childhood malignancy, making it the most common cancer in that age group [3]. There are two subtypes of the disease T-cell ALL (T-ALL) and B-cell precursor ALL (BCP-ALL), T-ALL involves thymocytes and responsible for about $15 \%$ of childhood and $25 \%$ of adult ALL [4]. TAL1 was also found to be related to many human hematological diseases such as lymphoblastic lymphoma, immunodeficiency 18, acute myeloid leukemia and diamond-black fan Anemia [5-9].

Although the local alterations or chromosome translocation in committed T-cell precursors is associated with the development of T-ALL [10-12], literature review revealed that there are no previous studies on the effect of such alterations on TAL1 structure and function. Therefore the aim of the present work was to conduct a full in silico analysis of TAL1's SNPs using bioinformatics prediction tools to study the possible effect of the genetic variations on the protein structure and function.

Studies showed that tumor-specific activation of $T A L 1$ is found in 40-60\% of T-ALL patients, resulting from interstitial chromosome mutations (25-30\%), chromosomal translocation (4-5\%) or by undefined mechanisms (60\%) [13-16]. These mutations are expected to be because of single nucleotide polymorphisms (SNPs), which are the most well known kind of genetic variation among individuals, consisting about $90 \%$ of genetic polymorphisms [17]. One type of SNPs is the non-synonymous SNPs (nsSNPs), also known as missense SNPs, which are very important because they are responsible for changes in human proteins' functions by substituting amino acid residues [18].

Therefore, early prediction and better understanding of the TAL1 gene functions could help in improving the prognosis of the disease. As this analysis is the first precise and broad computational study of functional SNPs in the TAL1 gene, it might be of great help in the near future for inventing early diagnostic and therapeutic measures for T-ALL. 


\section{Materials and Methods}

\section{SNPs Retrieval}

Polymorphisms in TAL1 gene were retrieved from the national center of biotechnology information database; dbSNP/NCBI database NCBI [19]. The retrieved SNPs were then filtered for investigation.

\section{Insilico analysis of non-synonymous single nucleotide polymorphisms (nSNPs)}

Different soft-wares were utilized to study the impact of SNPs mutations on TAL1 protein structure and function. Deleterious effect of nSNPs was investigated by SIFT and Polyphen-2 softwares. Stability changes was explored by I mutant-3. The association of nsSNPs with disease was done by PhD-SNP programming. The auxiliary changes in $3 \mathrm{D}$ structure were dissected utilizing Chimera programming. SNPs at the 3'UTR were likewise broke down to identify the impact on microRNA restricting destinations utilizing PolymiRTs programming. TAL1 gene interactions were investigated using GENEMANIA. In this study, nsSNPs and those at the 3'UTR regions were selected for analysis.

\section{Investigation of TAL1 Gene's Interactions and Appearance in Networks in GENEMANIA Database}

The online database GENEMANIA studies the gene function and interrelation with other genes using functional association data including protein and genetic interactions, pathways, co-expression, colocalization and protein domain similarity. It can also be used to find new members of a pathway or complex, find additional genes that may have been missed in screening or find new genes with a specific function, such as protein kinases [20]. Available at: http://www.genemania.org/.

\section{nsSNPs' Structural impact}

Functional effects of nsSNPs were analyzed using SIFT (http://sift.bii.a-star.edu.sg/) in which SNPs are characterized into tolerated and deleterious. The input SNPs' rs-IDs were submitted to the server for analysis, prediction was given as a tolerance index (TI) score going from 0.0 to 1.0. SNPs with TI score under 0.05 were anticipated to be deleterious; those more prominent than or equal to 0.05 were anticipated to be tolerated (http://blocks.fhcrc.org/sift/SIFT.html) [21].

\section{Prediction of Deleterious nsSNPs}

Polyphen software (Polymorphism Phenotyping v2; http://genetics.bwh.harvard.edu/ pph2) calculates position-specific independent count (PSIC) scores of which 1.0 is considered to be damaging. The SNPs are appraised quantitatively as benign, possibly damaging and probably damaging [22]. Positions of 
interest and new residue in protein FASTA sequence were submitted to Polyphen to investigate the functional effect of mutations.

Damaging SNPs in the above softwares were further analyzed by I mutant and PhD servers to estimate their effects on protein stability and disease associated variations, respectively.

\section{nsSNPs' Impact on Protein Stability}

\section{I-Mutant3.0 server}

I-Mutant is a web server for the automatic prediction of protein stability changes upon single-site mutations starting from the protein structure or sequence. It calculates the free energy change value (DDG) and predicts the indication of the free energy change value (DDG) (increase or decrease), along with a reliability index for the results (RI: $0-10$, where 0 is the minimum reliability and 10 is the maximum reliability). A DDG $<0$ corresponds to a decline in protein stability, whereas a DDG $>0$ corresponds to an increase in protein stability [23]. The residues changes and protein sequence in FASTA format were submitted to I-mutant server to process DDG value ( $\mathrm{kcal} / \mathrm{mol})$ and the RI value. Conditions for all enteries were set at temperature $25^{\circ} \mathrm{C}$ and $\mathrm{pH}$ 7.0. Available at http://gpcr2.biocomp.unibo.it/cgi/predictors/I-Mutant3.0/IMutant3.0.cgi.

\section{Prediction of Disease Associated Variations}

PhD-SNP is Support Vector Machine based classifier that predicts the disease associated variations upon single point mutation [24-26]. The residues changes and protein sequence in FASTA format were submitted to PhD-SNP server for the analysis. Available at: http://snps.biofold.org/phd-snp/phdsnp.html.

\section{Prediction of the Impact of SNPs at the 3Un Translated Region (3'UTR) by PolymiRTS Database}

PolymiRTS (v3.0) database is designed specifically for the analysis of non-coding SNPs at 3'UTR and identification of nSNPS that affect miRNA (micro RNA) targets in human and mouse [27]. 3'UTR SNPs in TAL1 gene were analyzed in order to investigate the alteration of miRNA binding on target sites which may result in diverse functional consequences. Available at: http://compbio.uthsc.edu/miRSNP.

\section{Project hope}

HOPE is an online service, developed at the Centre for Molecular and BiomolecularInformatics $\underline{\mathrm{CMBI}}$ at Radboud University in Nijmegen. It gathers structural information from different sources, including calculations on the 3D protein structure, succession comments in UniProt and expectation from the Reprof software. HOPE consolidates this data to analyze the impact of specific mutation on the protein structure [28]. 


\section{Homology modeling}

The 3D models for protein wild type and mutated were produced utilizing two homology modeling portals; Phyre2 and Raptorx [29, 30]. The obtained structures were then visualized by Chimera 1.10.2

\section{UCSF Chimera}

It is an extensible program for interactive representation and investigation of molecular structures and related information, including density maps, supramolecular gathering, sequence arrangement, docking results and conformational ensembles [31]. Chimera [32] can give the 3D structure of the protein and then changing between wild and mutant amino acids with the candidate to show the resulted effect. Chimera accepts the input in the form of pdb ID or pdb file. (https://www.cgl.ucsf.edu/chimera/).

\section{Predicting post translational modification (PTM) sites}

The phosphorylation sites of TAL 1 at serine, threonine and tyrosine residues were predicted by NetPhos server [33]. The ubiquitylation sites at lysine residue were investigated by UbPred and BDM-PUB tools [34]. 
bioRxiv preprint doi: https://doi.org/10.1101/447540; this version posted October 19, 2018. The copyright holder for this preprint (which was not certified by peer review) is the author/funder. All rights reserved. No reuse allowed without permission.

\section{Results}

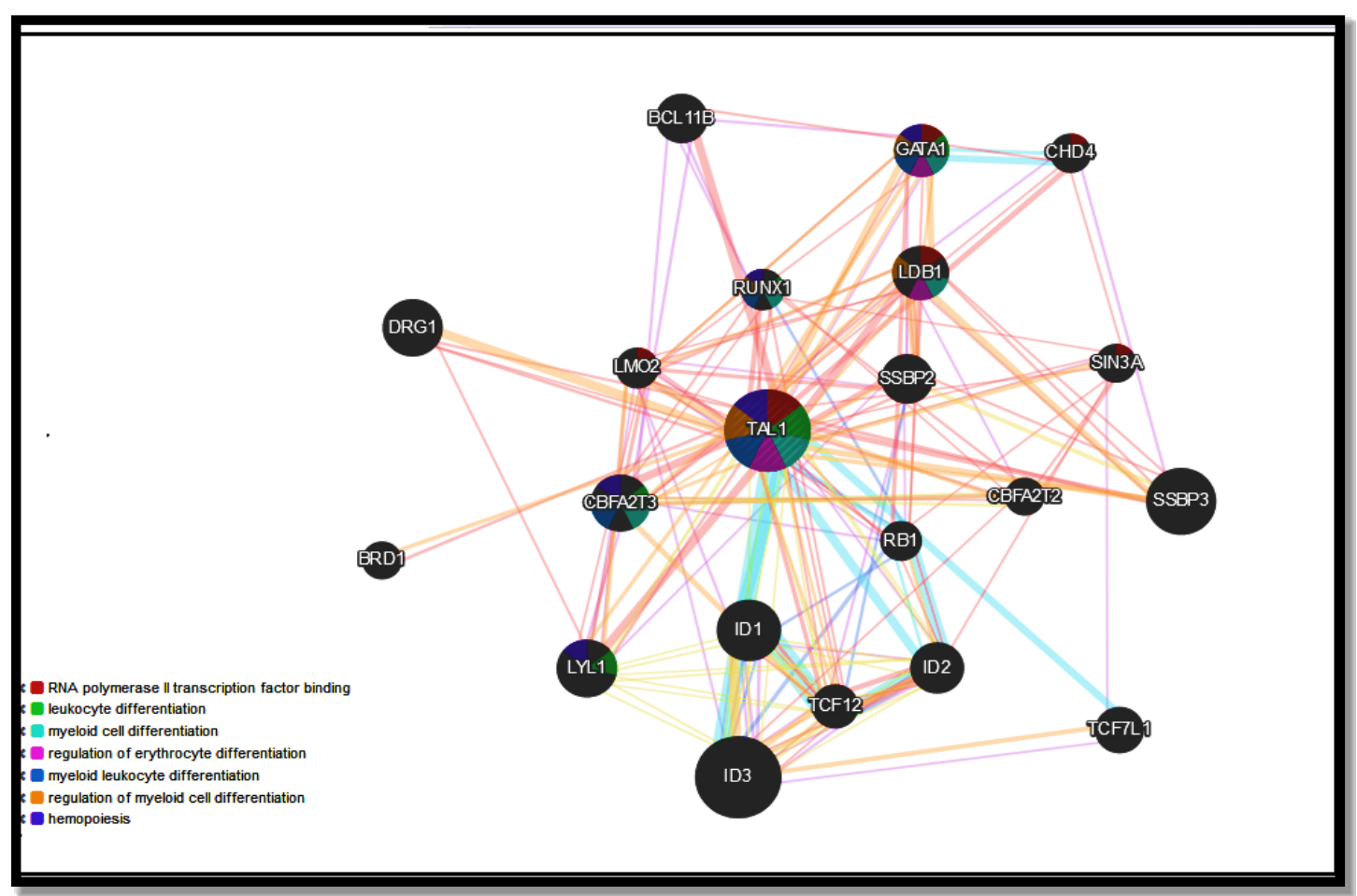

Figure 1: shows functional interaction between $T A L 1$ and its related genes 


\begin{tabular}{|c|c|c|c|c|}
\hline Gene symbol & Description & Co-expression & $\begin{array}{l}\text { Physical } \\
\text { interaction }\end{array}$ & $\begin{array}{l}\text { shared } \\
\text { domain }\end{array}$ \\
\hline ID3 & $\begin{array}{l}\text { inhibitor of DNA binding } 3 \text {, } \\
\text { HLH protein }\end{array}$ & $\mathrm{NO}$ & $\mathrm{NO}$ & YES \\
\hline$S S B P 3$ & $\begin{array}{l}\text { single stranded DNA binding } \\
\text { protein } 3\end{array}$ & NO & YES & NO \\
\hline ID1 & $\begin{array}{l}\text { inhibitor of DNA binding } 1 \text {, } \\
\text { HLH protein }\end{array}$ & NO & $\mathrm{NO}$ & YES \\
\hline LYL1 & $\begin{array}{lr}\text { lymphoblastic } & \text { leukemia } \\
\text { associated } & \text { hematopoiesis } \\
\text { regulator } 1 & \end{array}$ & NO & YES & YES \\
\hline$D R G 1$ & $\begin{array}{l}\text { developmentally regulated } \\
\text { GTP binding protein } 1\end{array}$ & NO & YES & NO \\
\hline CBFA2T3 & $\begin{array}{l}\text { CBFA2/RUNX1 translocation } \\
\text { partner } 3\end{array}$ & NO & YES & NO \\
\hline$L D B 1$ & LIM domain binding 1 & NO & YES & NO \\
\hline GATA1 & GATA binding protein 1 & YES & YES & NO \\
\hline ID2 & $\begin{array}{l}\text { inhibitor of DNA binding } 2 \text {, } \\
\text { HLH protein }\end{array}$ & YES & $\mathrm{NO}$ & YES \\
\hline$S S B P 2$ & $\begin{array}{l}\text { single stranded DNA binding } \\
\text { protein } 2\end{array}$ & NO & YES & NO \\
\hline$B C L 11 B$ & B-cell CLL/lymphoma 11B & NO & YES & NO \\
\hline TCF7L1 & transcription factor 7 like 1 & NO & $\mathrm{NO}$ & NO \\
\hline TCF 12 & transcription factor 12 & NO & YES & YES \\
\hline$R U N X 1$ & $\begin{array}{l}\text { runt related transcription factor } \\
1\end{array}$ & NO & YES & NO \\
\hline$L M O 2$ & LIM domain only 2 & YES & YES & NO \\
\hline$R B 1$ & $\begin{array}{l}\text { RB transcriptional corepressor } \\
1\end{array}$ & NO & YES & NO \\
\hline CHD4 & $\begin{array}{l}\text { chromodomain helicase DNA } \\
\text { binding protein } 4\end{array}$ & NO & YES & NO \\
\hline $\operatorname{SIN} 3 A$ & $\begin{array}{l}\text { SIN3 transcription regulator } \\
\text { family member A }\end{array}$ & YES & YES & NO \\
\hline$B R D 1$ & bromodomain containing 1 & NO & Yes & NO \\
\hline$C B F A 2 T 2$ & $\begin{array}{l}\text { CBFA2/RUNX1 translocation } \\
\text { partner } 2\end{array}$ & NO & Yes & NO \\
\hline
\end{tabular}

Table1. Shows the genes co-expressed, physical interaction and share a domain with $T A L 1$ 
bioRxiv preprint doi: https://doi.org/10.1101/447540; this version posted October 19, 2018. The copyright holder for this preprint (which was not certified by peer review) is the author/funder. All rights reserved. No reuse allowed without permission. 
Table2. Illustrates the TAL1 functions and its appearance in network and genome

\begin{tabular}{|c|c|c|c|c|}
\hline Function & $*$ FDR & $\begin{array}{l}\text { Genes } \\
\text { network }\end{array}$ & in & Genes in genome \\
\hline $\begin{array}{l}\text { RNA polymerase II transcription factor } \\
\text { binding }\end{array}$ & $2.40746 \mathrm{E}-06$ & 6 & & 74 \\
\hline granulocyte differentiation & $1.72765 \mathrm{E}-05$ & 4 & & 16 \\
\hline regulatory region DNA binding & 4.0226E-05 & 7 & & 268 \\
\hline regulatory region nucleic acid binding & $4.0226 \mathrm{E}-05$ & 7 & & 268 \\
\hline transcription factor complex & $4.30288 \mathrm{E}-05$ & 6 & & 155 \\
\hline $\begin{array}{l}\text { transcription regulatory region DNA } \\
\text { binding }\end{array}$ & 0.000906689 & 6 & & 267 \\
\hline myeloid cell differentiation & 0.002041367 & 5 & & 165 \\
\hline regulation of erythrocyte differentiation & 0.003955733 & 3 & & 22 \\
\hline myeloid leukocyte differentiation & 0.006093148 & 4 & & 94 \\
\hline regulation of myeloid cell differentiation & 0.00610707 & 4 & & 97 \\
\hline leukocyte differentiation & 0.00610707 & 5 & & 226 \\
\hline Hemopoiesis & 0.00636298 & 5 & & 232 \\
\hline $\begin{array}{l}\text { negative regulation of sequence-specific } \\
\text { DNA binding transcription factor activity }\end{array}$ & 0.007074313 & 4 & & 107 \\
\hline $\begin{array}{l}\text { RNA polymerase II activating } \\
\text { transcription factor binding }\end{array}$ & 0.007230266 & 3 & & 32 \\
\hline $\begin{array}{l}\text { hematopoietic or lymphoid organ } \\
\text { development }\end{array}$ & 0.007328562 & 5 & & 250 \\
\hline immune system development & 0.009460283 & 5 & & 267 \\
\hline histone deacetylase complex & 0.01368668 & 3 & & 42 \\
\hline histone $\mathrm{H} 3$ acetylation & 0.01489199 & 3 & & 44 \\
\hline erythrocyte differentiation & 0.015105508 & 3 & & 45 \\
\hline $\begin{array}{l}\text { positive regulation of myeloid cell } \\
\text { differentiation }\end{array}$ & 0.016375495 & 3 & & 47 \\
\hline activating transcription factor binding & 0.016623954 & 3 & & 48 \\
\hline response to thyroid hormone & 0.043653839 & 2 & & 10 \\
\hline Chromatin & 0.059999159 & 4 & & 213 \\
\hline $\begin{array}{l}\text { positive regulation of erythrocyte } \\
\text { differentiation }\end{array}$ & 0.08071214 & 2 & & 14 \\
\hline regulation of chromosome organization & 0.092141062 & 3 & & 90 \\
\hline $\begin{array}{l}\text { regulation of transcription regulatory } \\
\text { region DNA binding }\end{array}$ & 0.098119367 & 2 & & 16 \\
\hline
\end{tabular}

*False discovery rate is greater than or equal to the probability that this is a false positive 


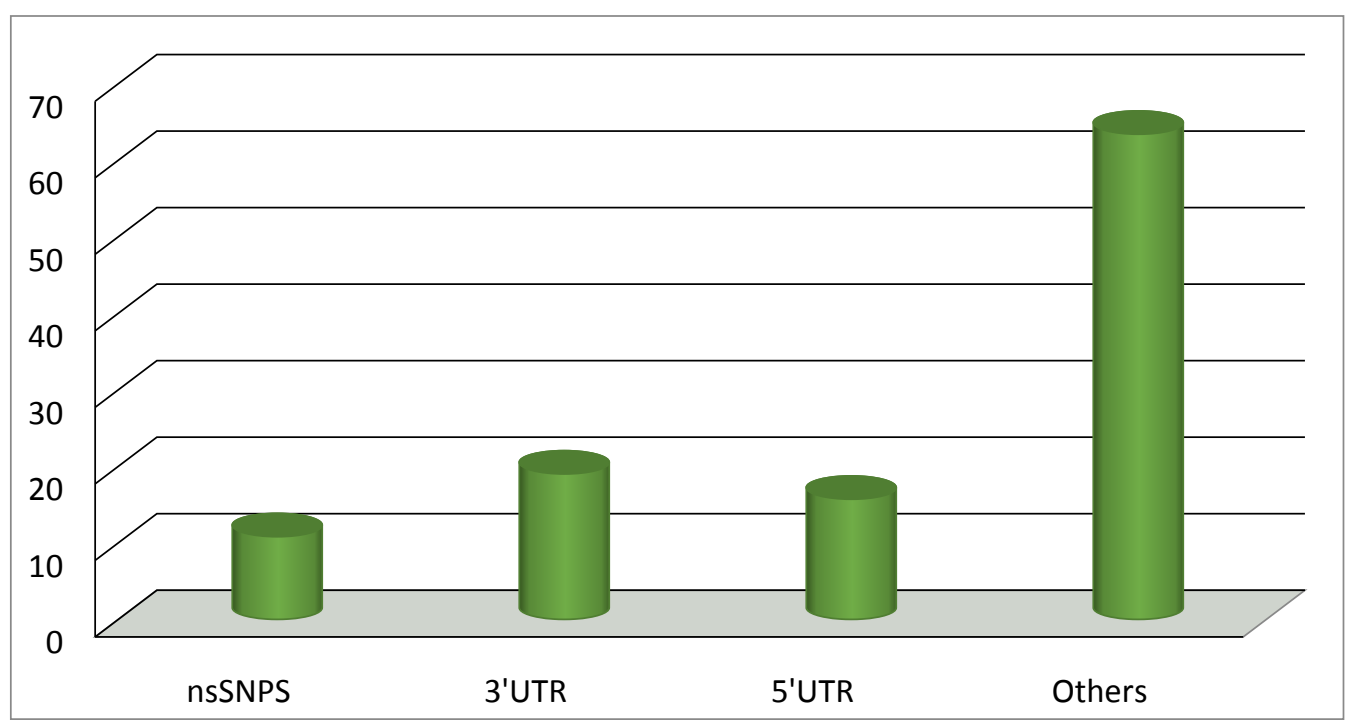

Figure 2: Percentages of the SNPs in TAL1 gene. (nsSNPs: 10.8\%; 3'UTR SNPs: 19\%; 5'UTR SNPs: 15.7\%; Other SNPs: 63\%) 


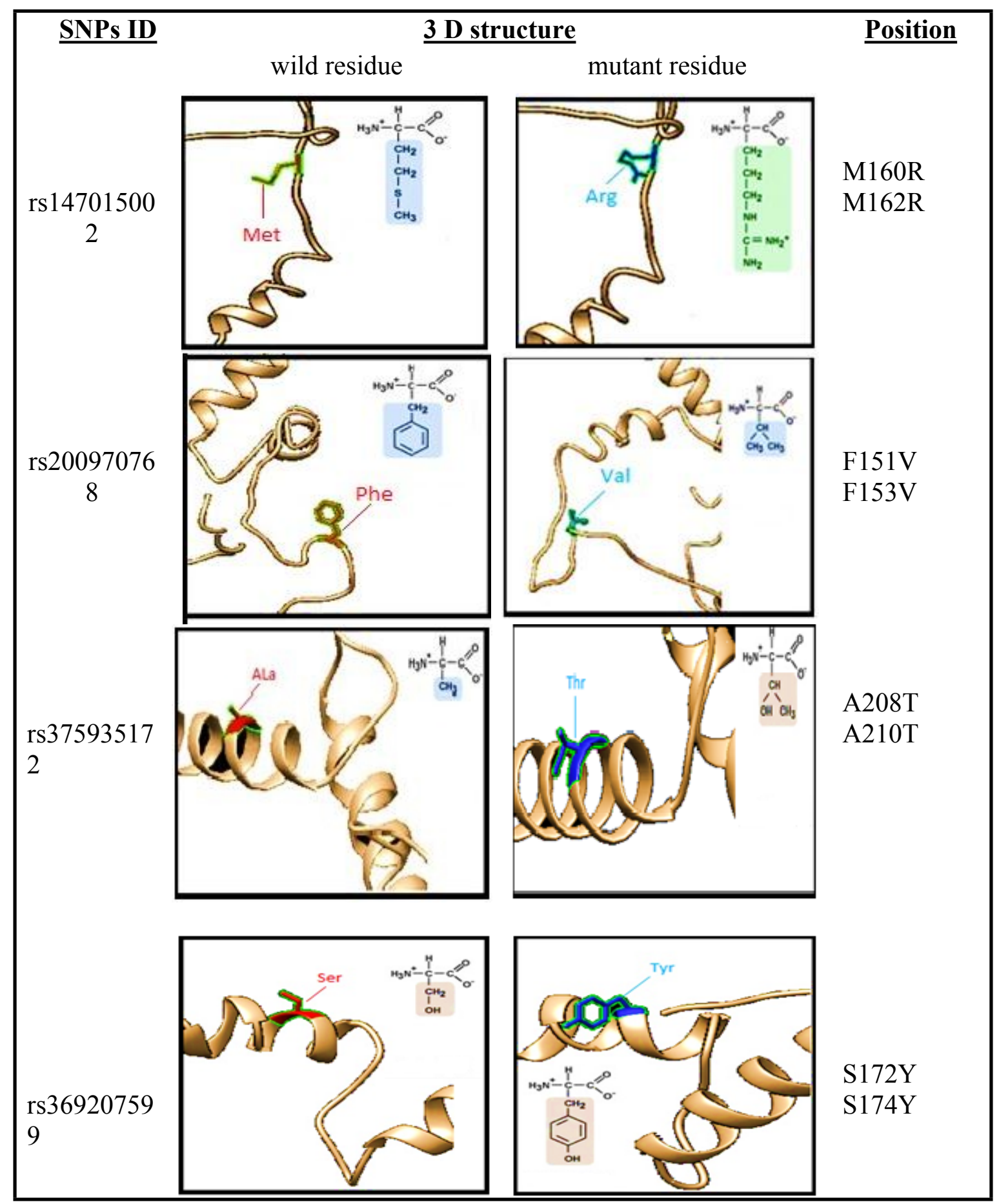

Figure 3. 3D model of $T A L 1$ protein (visualized by Chimera 1.10.2). 
Table 3. Represents prediction results of SIFT, Polyphen, I mutant and PhD-SNP

\begin{tabular}{|c|c|c|c|c|c|c|c|c|c|c|}
\hline \multirow[b]{2}{*}{ SNP } & \multirow[b]{2}{*}{$\begin{array}{l}\text { Amino } \\
\text { Acid } \\
\text { Change }\end{array}$} & \multirow[b]{2}{*}{$\begin{array}{l}\text { Sift } \\
\text { Score }\end{array}$} & \multirow[b]{2}{*}{$\begin{array}{l}\text { Sift } \\
\text { Prediction }\end{array}$} & \multirow[b]{2}{*}{$\begin{array}{l}\text { Polyphen } \\
\text { score }\end{array}$} & \multirow[b]{2}{*}{$\begin{array}{l}\text { Polyphen } \\
\text { prediction }\end{array}$} & \multicolumn{3}{|l|}{ I mutant } & \multicolumn{2}{|c|}{ PhD-SNP } \\
\hline & & & & & & SVM2 & DDG & $\begin{array}{l}\mathbf{R} \\
\mathbf{I}\end{array}$ & Effect & $\begin{array}{l}\mathbf{R} \\
\mathbf{I}\end{array}$ \\
\hline $\begin{array}{l}\text { rs } 14701500 \\
2\end{array}$ & M160R & 0.009 & Deleterious & 0.835 & $\begin{array}{l}\text { Possibly } \\
\text { damaging }\end{array}$ & Decrease & -1.08 & 2 & Neutral & 1 \\
\hline $\begin{array}{l}\text { rs } 14701500 \\
2\end{array}$ & M162R & 0.01 & Deleterious & 0.835 & $\begin{array}{l}\text { Possibly } \\
\text { damaging }\end{array}$ & Decrease & -1.08 & 2 & Neutral & 1 \\
\hline $\begin{array}{l}\text { rs20097076 } \\
8\end{array}$ & F151V & 0.013 & Deleterious & 0.615 & $\begin{array}{l}\text { Possibly } \\
\text { damaging }\end{array}$ & Decrease & -0.99 & 6 & Neutral & 5 \\
\hline $\begin{array}{l}\text { rs20097076 } \\
8\end{array}$ & F153V & 0.035 & Deleterious & 0.745 & $\begin{array}{l}\text { Possibly } \\
\text { damaging }\end{array}$ & Decrease & -1.07 & 6 & Neutral & 5 \\
\hline $\begin{array}{l}\text { rs36920759 } \\
9\end{array}$ & S172Y & 0.004 & Deleterious & 0.981 & $\begin{array}{l}\text { Probably } \\
\text { damaging }\end{array}$ & Increase & -0.29 & 2 & Disease & 1 \\
\hline $\begin{array}{l}\text { rs36920759 } \\
9\end{array}$ & S174Y & 0.006 & Deleterious & 0.939 & $\begin{array}{l}\text { Probably } \\
\text { damaging }\end{array}$ & Increase & -0.29 & 2 & Disease & 1 \\
\hline $\begin{array}{l}\text { rs37593517 } \\
2\end{array}$ & A210T & 0.006 & Deleterious & 0.97 & $\begin{array}{l}\text { Probably } \\
\text { damaging }\end{array}$ & Decrease & -0.79 & 8 & Disease & 5 \\
\hline $\begin{array}{l}\text { rs } 37593517 \\
2\end{array}$ & $\mathrm{~A} 208 \mathrm{~T}$ & 0.006 & Deleterious & 0.97 & $\begin{array}{l}\text { Probably } \\
\text { damaging }\end{array}$ & Decrease & -0.79 & 8 & Disease & 4 \\
\hline
\end{tabular}

*DDG: free energy change value; SVM2: support vector machine; RI: reliability index 
bioRxiv preprint doi: https://doi.org/10.1101/447540; this version posted October 19, 2018. The copyright holder for this preprint (which was not certified by peer review) is the author/funder. All rights reserved. No reuse allowed without permission.

Table 4. Shows SNPs and INDELs in miRNA target sites

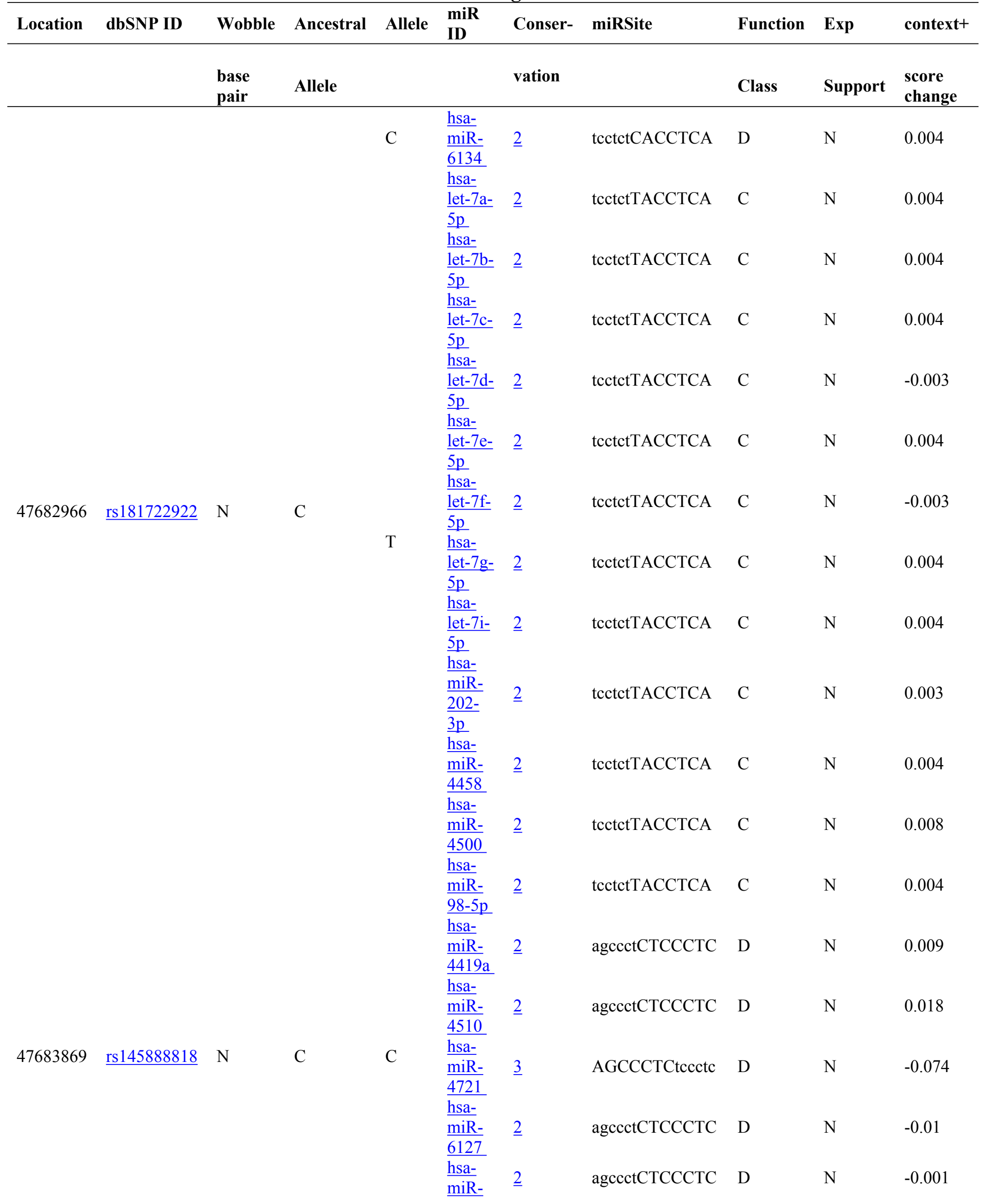




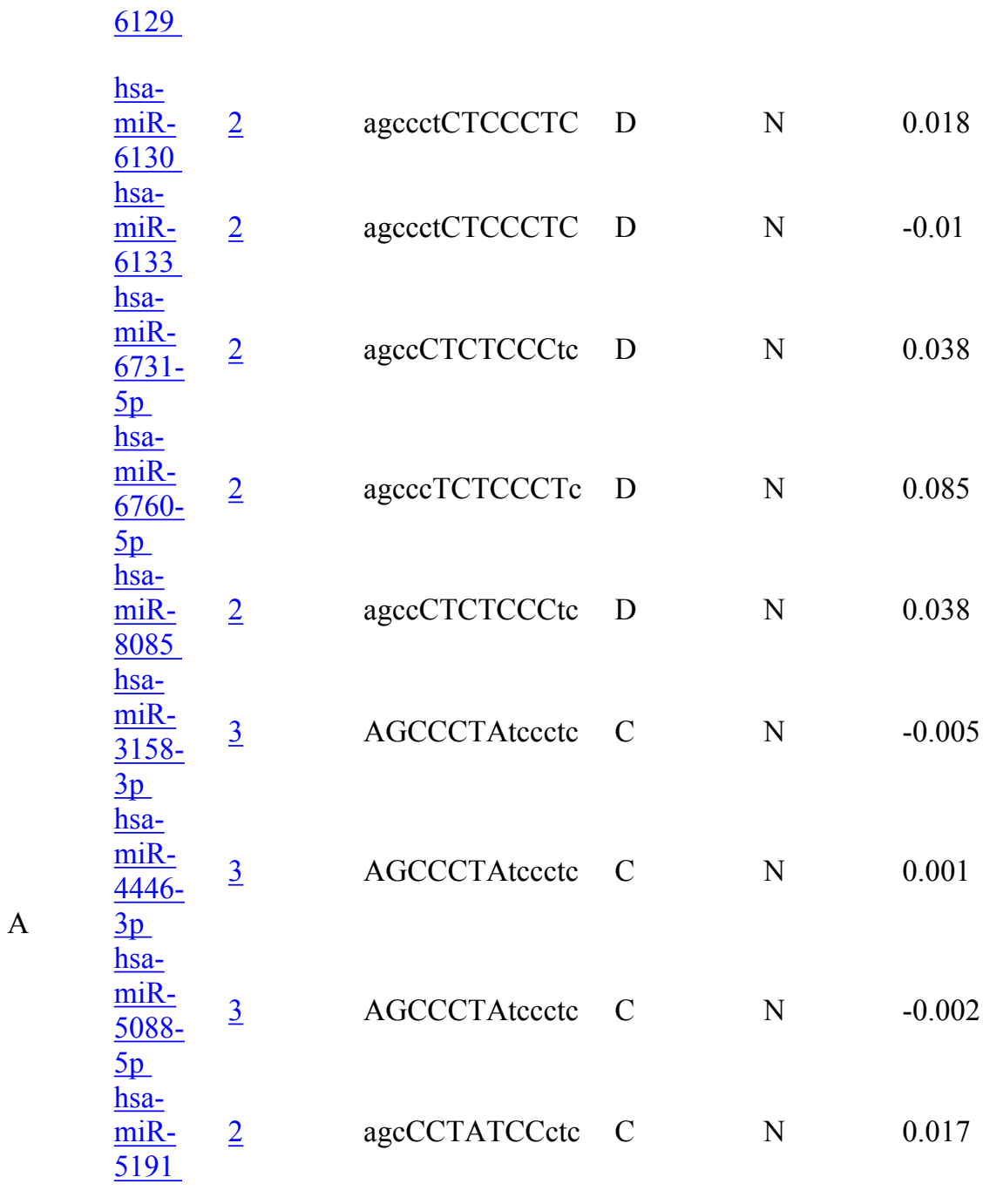

* Function Class:

D: The derived allele disrupts a conserved miRNA site (ancestral allele with support $\geq 2$ ).

$\mathrm{N}$ : The derived allele disrupts a nonconserved miRNA site (ancestral allele with support $<2$ ).

C: The derived allele creates a new miRNA site.

O: The ancestral allele cannot be determined. 
Table 5: Phosphorylation sites predicted by NetPhos 3.1

\begin{tabular}{llllll}
\hline $\begin{array}{l}\text { Serine } \\
\text { Position }\end{array}$ & Score & Position & Score & Position & Score \\
\hline 49 & 0.739 & 73 & 0.973 & 23 & 0.518 \\
70 & 0.870 & 112 & 0.937 & 375 & 0.969 \\
78 & 0.986 & 161 & 0.559 & & \\
83 & 0.804 & 255 & 0.552 & & \\
193 & 0.898 & 263 & 0.693 & \\
217 & 0.728 & 322 & 0.946 & & \\
243 & 0.998 & 327 & 0.979 & & \\
265 & 0.984 & & & \\
295 & 0.978 & & & \\
357 & 0.807 & & & \\
360 & 0.531 & & & \\
364 & 0.822 & & & \\
371 & 0.785 & & & \\
374 & 0.996 & & & \\
387 & 0.621 & & & \\
\hline
\end{tabular}

Table 6: Ubiquitylation sites predicted by Ub-Pred and BDM-PUB

\begin{tabular}{llll}
\hline $\begin{array}{l}\text { Ub-Pred } \\
\text { Position }\end{array}$ & Score & $\begin{array}{l}\text { BD-PUB } \\
\text { Position }\end{array}$ & Score \\
\hline 39 & 0.80 & 75 & 2.84 \\
75 & 0.84 & 221 & 2.60 \\
255 & 0.84 & 222 & 1.49 \\
258 & 0.79 & 225 & 2.70 \\
311 & 0.92 & 255 & 0.93 \\
& & 258 & 1.60 \\
& & 311 & 1.02 \\
\hline
\end{tabular}


bioRxiv preprint doi: https://doi.org/10.1101/447540; this version posted October 19, 2018. The copyright holder for this preprint (which was not certified by peer review) is the author/funder. All rights reserved. No reuse allowed without permission.

\section{Discussion}

Genetic polymorphism in TAL1 gene was found sharing protein domain (bHLH domain) with five genes and associated in many diseases such as lymphoblastic leukemia, craniosynostosis, anemia and fibrodysplasia ossificans progressive.

Our present study detected eight SNPs in TAL1 coding region to be highly damaging. The interesting finding was that the clinical significance for the four disease-related SNPs was unknown in the dbSNP/NCBI database. Insilico analysis of single nucleotide polymorphisms (SNPs) has become a valuable and essential tool for prediction of variants most likely associated with disease. This approach has been done for many disorders especially for cancer related genes [35-38]. Our methods in bioinformatics analysis were in conjunction with previous papers analyzing disease-related genes such as VCAM-1, MSH6, GRM4, MYC and TAGAP genes [39-43].

TAL1 has similar expression to four genes which are mainly either inhibitors of protein binding or regulating transcription binding factors (Figure 1, Table 1). It has many molecular functions; it enables RNA polymerase II transcription factor activity and colocalizes with histone deacetylase complex. HSCs undergo differentiation when TAL1 activates transcription by recruiting a core complex DNA consisting of E2A/HEB, GATA1/2/3, $L M O 1 / 2, L D B 1$, and an additional complex comprising ETO2, RUNX1, ERG or FLI1 [44]. The TAL1's regulatory functions (lineage priming, activation, and repression of gene expression programs) give knowledge into principal developmental and transcriptional components and features mechanistic parallels between typical and oncogenic processes [45]. Also, Bae et al found that one intronic SNP of TAL1 gene (rs2250380) was significantly associated with Schizophrenia [46].

Four thousand two hundred and twelve SNPs in TAL1 gene were retrieved from dbSNP/NCBI in May 2018. There were nsSNPs, 3'UTR, 5'UTR and others (Figure 2). All nsSNPs in the coding region were subjected to different tools to test their effect on protein function and stability. Ninety nsSNPs were determined by SIFT to be tolerated or deleterious. According to Polyphen2, they were found to be benign, possibly or probably damaging. SNPs which scored $\leq 0.05$ in SIFT and $\sim 1$ in Polyphen-2 were then selected so that only the deleterious and damaging ones would be analyzed.

The eight shortlisted damaging SNPs were further analyzed by I-Mutant to predict the effect of the mutant amino acids on the protein steadness. The obtained results reflected that the stability with related free energy will be different due to mutation. Six SNPs $(M \rightarrow R, F \rightarrow V, A \rightarrow T$ in different positions) had decrease effect on stability with DDG values ranged between $-0.79--1.08$, while the two SNPs (S $\rightarrow$ Y; rs369207599) increase the stability of protein and also analyzed to be disease related using PHD- SNPs software (Table 3).

The rs375935172 caused amino acid substitution A208T and A210T. The mutant residue is bigger and more hydrophilic than the wild-type residue, which may cause loss of interactions with other 
molecules on the surface of the protein. This mutation is the most important as it is situated in the bHLH domain. The change presents an amino acid with various properties, which can disturb this domain and abrogate its function. The mutated residue is situated in a domain that is essential for binding of other molecules. It is possible that the mutation affects these contacts and might influence the interaction disturb signal transfer from binding domain to the activity domain.

The rs147015002 results in the substitution of amino acid M to $R$ at positions 160 and 162 . The original wild-type residue and newly introduced mutant residue differ in their specific size, charge, and hydrophobicity-value. The mutant residue is bigger than the wild-type residue which might lead to bumps. The wild-type residue charge was neutral; the mutant residue charge is positive which can cause repulsion of ligands or other residues with the same charge. The wild-type residue is more hydrophobic than the mutant residue. Hydrophobic interactions, either in the core of the protein or on the surface, will be lost.

The rs200970768 caused conversion of amino acid $\mathrm{F}$ to smaller amino acid V at position 151 or 153 , while the rs369207599 result in replacement of S into Y at position 172 or 174 which differ in size. The mutant residue is bigger and this might lead to bumps. The mutant residue prefers to be in another secondary structure; therefore, the local conformation will be slightly destabilized (Figure 3). Functional SNPs in three translated region in TAL1 gene was analyzed using PolymiRTS software. Among 227 SNPs in 3'UTR there were only 48 functional SNPs predicted (S1 Table). rs 181722922 SNP contain (C) allele has 12 miRNA Sites as Target binding site can create a new microRNA site. rs145888818 SNP contain (D) allele has 10 miRNA Sites which they are derived allele that disrupts a conserved miRNA sit (Table 4).

PTMs are imperative in directing structures and functions of proteins hence are engaged in numerous biological events, for example, protein-protein interactions and cell signaling etc [47, 48]. Phosphorylation of proteins is an essential regulatory mechanism as it changes the structural conformation of a protein, resulting in making it to become activated, deactivated, or altering its function [49]. Target amino acid is usually serine, threonine or tyrosine residues. Net Phos predicted 15 Serine, 7 Threonine and 2 Tyrosine residues which have high potentiality to be phosphorylated (Table 5). Ubiquitination (or ubiquitylation) is an enzymatic post-translational modification in which an ubiquitin protein is linked to a substrate protein. It changes cellular process by regulating the decomposition of proteins (via the proteasome and lysosome), arranging the cellular localization of proteins, activating and inactivating proteins, and modulating protein-protein interactions [50-52]. UbPred and BDM-PUB tools predicted five and seven Lysine residues, respectively which undergo ubiquitylation (Table 6). Although PTMs are not coincided in position with the nsSNPs in TAL1 gene, results by similarity revealed that phosphorylation of Ser-122 in TAL1gene is strongly 
stimulated by hypoxia and subsequently ubiquitination targets the protein for rapid degradation via the ubiquitin system (Table 6). This process may be characteristic for microvascular endothelial cells, since it could not be observed in large vessel endothelial cells.

\section{Conclusion}

This study predicted that the stability and function of $T A L 1$ protein is affected by eight high risk nsSNP. One of these mutationS (rs375935172) is located at the highly conserved bHLH domain region, hence it is of high concern as this is the only functional region of the protein. In addition to these findings, the study identifies several TAL1 sites that undergo post transitional modification. Therefore, further investigations and wet lab experimentation are required to determine the effects of these polymorphisms on the protein function which can be a hit for discovering new drugs.

\section{Funding}

The author(s) received no financial support for the research, authorship, and/or publication of this article.

\section{References}

1. ((AML): Practice Essentials, Pathophysiology, Etiology. [online] Emedicine.medscape.com. Available at: http://emedicine.medscape.com/article/197802-overview [Accessed 21 Apr. 2018].

2. Disease-ontology. Acute leukemia. [online] Available at: http://diseaseontology.org/term/DOID\%3A12603/ [Accessed 8 May 2018].

3. Harisson CJ. Acute Lymphoblastic Leukemia. Clinics in Laboratory Medicine. 2011; 31(4): 631-647.

4. Ward E, DeSantis C, Robbins A, Kohler B, Jemal A. Childhood and adolescent cancer statistics. CA: A Cancer Journal for Clinicians. 2014; 64(2): 83-103.

5. Orpha. TAL1TAL bHLH transcription factor 1, erythroid differentiation factor [online] Available at http://www.orpha.net/consor/cgibin/Disease_Genes.php?lng=EN\&data_id=15576 [Accessed 31 May 2018]

6. Sanda T, Leong WZ. TAL1 as a master oncogene transcription factor in T-cell acute lymphoblastic leukemia. Exp Hematol. 2017; 53: 7-15.

7. Han X, Bueso-Ramos CE. Precursor T-cell acute lymphoblastic leukemia/lymphoblastic lymphoma and acute biphenotypic leukemias. Am J Clin Pathol. 2007; 127(4): 528-44. 
8. Fasseu M, Aplan PD, Chopin M, Boissel N, Bories JC, Soulier J, von Boehmer H, Sigaux F, Regnault A. p16INK4A tumor suppressor gene expression and CD3epsilon deficiency but not pre-TCR deficiency inhibit TAL1-linked T-lineage leukemogenesis. Blood. 2007; 110(7): 2610-9.

9. Genecards. TAL1 Gene - Disorders. [online] Genecards.org. Available at: http://www.genecards.org/cgi-bin/carddisp.pl?gene=TAL1 [Accessed 31 May 2018].

10. Baer, R. TAL1, TAL2 and LYL1: a family of basic helix-loop-helix proteins implicated in T cell acute leukaemia. Semin Cancer Biol (1993);4(6):341-7.

11. Correia, N., Melão, A., Póvoa, V., Sarmento, L., de Cedrón, M., Malumbres, M., Enguita, F. and Barata, J. microRNAs regulate TAL1 expression in T-cell acute lymphoblastic leukemia. Oncotarget (2016);7(7):8268-81.

12. Cardoso, B., de Almeida, S., Laranjeira, A., Carmo-Fonseca, M., Yunes, J., Coffer, P. and Barata, J. TAL1/SCL is downregulated upon histone deacetylase inhibition in T-cell acute lymphoblastic leukemia cells. Leukemia (2011);25(10):1578-1586.

13. Brown L, Cheng JT, Chen Q, Siciliano MJ, Crist W, Buchanan G, et al. Site-specific recombination of the tal-1 gene is a common occurrence in human T cell leukemia. EMBO J (1990);9(10):3343-51.

14. Bash RO, Hall S, Timmons CF, Crist WM, Amylon M, Smith RG, et al. Does activation of the TAL1 gene occur in a majority of patients with T-cell acute lymphoblastic leukemia? A pediatric oncology group study. Blood (1995);86(2):666-76.

15. Carroll AJ, Crist WM, Link MP, Amylon MD, Pullen DJ, Ragab AH, et al. The $\mathrm{t}(1 ; 14)(\mathrm{p} 34 ; \mathrm{q} 11)$ is nonrandom and restricted to T-cell acute lymphoblastic leukemia: a Pediatric Oncology Group study. Blood (1990);76(6):1220-4.

16. Huret, JL., Labastie, MC., Huret, JL., Labastie MC. TAL1 (T-cell acute leukemia 1). Atlas Genet Cytogenet Oncol Haematol. (1998);2(2):47-48.

17. Collins FS, Brooks LD, Chakravarti A, A DNA polymorphism discovery resource for research on human genetic variation. Genome Res (1998);8:1229-1231.

18. Lander ES. The new genomics: global views of biology. Science. 1996.

19. $S N P$ - NCBI. [online] Available at http://www.ncbi.nlm.nih.gov/snp [Accessed in March 2018]

20. GENEMANIA. [online] Available at http://pages.genemania.org/. [Accessed in March 2018]

21. Nahla E. Abdelraheem, Marwa Mohamed Osman, Osama Muhieldin Elgemaabi, Afra Abdelhamid Fadl Alla, Mosab Mohamed Ismail, Soada Ahmed Osman, Aisha Ismail Ibrahim, Nihad Elsadig Babekir4, Salwa Osman Mekki, Mohamed A. Hassan. Computational 
Analysis of Deleterious Single Nucleotide Polymorphisms (SNPs) in Human MutS Homolog6 (MSH6) Gene American Journal of Bioinformatics Research (2016);6(2):56-97

22. Ivan Adzhubei, Daniel M. Jordan, Sunyaev S.R. Predicting Functional Effect of Human Missense Mutations Using PolyPhen-2. Current Protocols in Human Genetics. 7(20):1-41.

23. Capriotti E, Fariselli P, Casadio R I-Mutant2.0: predicting stability changes upon mutation from the protein sequence or structure. Nucleic Acids Res (2005);33:W306-10.

24. Capriotti E, Calabrese R and Casadio R.Predicting the insurgence of human genetic diseases associated to single point protein mutations with support vector machines and evolutionary information. Bioinformatics (2006);22: 2729-2734.

25. Capriotti E, Fariselli P, Calabrese R. and Casadio R. Predicting protein stability changes from sequences using support vector machines. Bioinformatics (2005);21(Suppl 2): ii54-ii58

26. Altschul S. F, Madden T. L, Schaffer A. A, Zhang J, Zhang. Z, Miller. W and Lipman D. J. Gapped. BLAST and PSI-BLAST: a new generation of protein database search programs. Nucleic Acids Research (1997);25: 3389-3402.

27. Jesse D, Ziebarth YC, Anindya Bhattacharya and Anlong Chen. PolymiRTS Database 2.0: linking polymorphisms in microRNA target sites with human diseases and complex traits. Nucleic Acids Research (2012);40(Database issue):D216-D221.

28. Venselaar, H., T. A. te Beek, R. K. Kuipers, M. L. Hekkelman and G. Vriend. Protein structure analysis of mutations causing inheritable diseases. An e-Science approach with life scientist friendly interfaces. BMC Bioinformatics (2010);11(1):548.

29. Kelley LA et al. The Phyre 2 web portal for protein modeling, prediction and analysis. Nature Protocols. 2015; 10: 845-858.

30. Källberg M, Wang H, Wang S, Peng J, Wang Z, Lu H, Xu H. Temple-based protein structure modelling using the RaptorX website server. Nature Protocols. 2012; 7: 1511-1522.

31. http://www.cgl.ucsf.edu/chimera/. Accessed in March 2018

32. Goddard TD1, Huang CC, Ferrin. TE Software extensions to UCSF chimera for interactive visualization of large molecular assemblies. J Structure (2005); 13(3):473-82.

33. Blom N, Gammeltoft S, Brunak S. Sequence and structure-based prediction of eukaryotic protein phosphorylationsites. J Mol Biol. 1999; 294: 1351 \pm 1362 . https://doi.org/10.1006/jmbi.1999.3310 PMID:10600390

34. Radivojac P, Vacic V, Haynes C, Cocklin RR, Mohan A, et al. (2010) Identification, analysis, and prediction of protein ubiquitination sites. Proteins 78: 365-380.

35. R. Rajasekaran, C. G. PriyaDoss, C. Sudandiradoss, K. Ramanathan, and R. Sethumadhavan, "In silico analysis of structural and functional consequences in p16INK4A by deleterious 
nsSNPs associated CDKN2A gene in malignant melanoma,” Biochimie (2008);90(10):15231529.

36. R. Rajasekaran and R. Sethumadhavan, "Exploring the cause of drug resistance by the detrimental missense mutations in KIT receptor: computational approach," Amino Acids (2010):39(3):651-660.

37. R. Rajasekaran, C. Sudandiradoss, C. G. P. Doss, and R. Sethumadhavan, "Identification and in silico analysis of functional SNPs of the BRCA1 gene," Genomics(2007);90(4):447-452.

38. R. Rajasekaran, C. George Priya Doss, C. Sudandiradoss, K. Ramanathan, R. Purohit, and R. Sethumadhavan, "Effect of deleterious nsSNP on the HER2 receptor based on stability and binding affinity with herceptin: a computational approach," Comptes Rendus-Biologies (2008);331(6):409-4

39. Alabid T, Kordofani AAY, Atalla B, Altayb HN, Fadla AA, et al. In silico Analysis of Single Nucleotide Polymorphisms (SNPs) in HumanVCAM-1 gene. J Bioinform, Genomics, Proteomics 2016; 1(1): 1004.

40. Alabid T, Kordofani AAY, Atalla B, Altayb HN, Fadla AA, et al. (2016) In silico Analysis of Single Nucleotide Polymorphisms (SNPs) in HumanVCAM-1 gene. JBioinform, Genomics, Proteomics 1(1): 1004.

41. Elshaikh AAF, Ismaiel MM, Osman MM, Shokri SAI et al. Computational Analysis of Single Nucleotide Polymorphism (SNPs) in Human GRM4 Gene. American Journal of Biomedical Research, 2016, Vol. 4, No. 3, 61-73

42. Fadlalla Elshaikh AAE, Elmahdi Ahmed MT, Daf Alla TIM, Mogammed Elbasheer AS, Ahmed AA, et al. (2016) Computational Analysis of Single Nucleotide Polymorphism (Snps) In Human MYC Gene. J Bioinform, Genomics, Proteomics 1(3): 1011.

43. Arshad M, Bhatti A, John P (2018)Identification and in silico analysis of functional SNPs of human TAGAP protein: A comprehensive study. PLoS ONE 13(1): e0188143

44. Hoang, T., Lambert, J. and Martin, R. SCL/TAL1 in Hematopoiesis and Cellular Reprogramming. Current Topics in Developmental Biology (2016); 188:163-204.

45. Porcher, C., Chagraoui, H. and Kristiansen, M. SCL/TAL1: a multifaceted regulator from blood development to disease. Blood (2017); 129(15):2051-2060.

46. Bae, J., Kim, H., Ban, J., Park, H., Kim, S., Kang, S., Park, J., Kim, J. and Chung, J. Association between polymorphisms of TAL1 gene and schizophrenia in a Korean population. Psychiatric Genetics (2012);22(1):50.

47. Dai C, Gu W. p53 post-translational modification: deregulated in tumorigenesis. Trends Mol

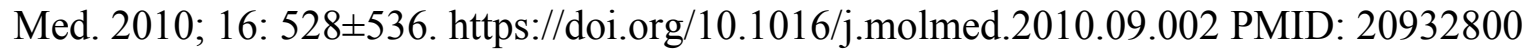


48. Shiloh Y, Ziv Y. The ATM protein kinase: regulating the cellular response to genotoxic

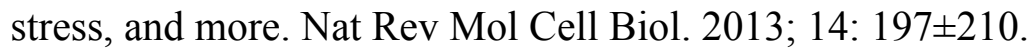

49. Ciesla J, Fraczyk T, Rode W. Phosphorylation of basic amino acid residues in proteins:

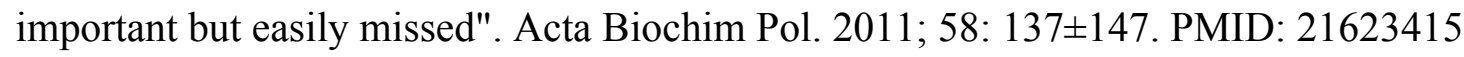

50. Glickman MH, Ciechanover A (April 2002). "The ubiquitin-proteasome proteolytic pathway: destruction for the sake of construction". Physiological Reviews. 82 (2): $373-$ 428. doi:10.1152/physrev.00027.2001. PMID 11917093.

51. Mukhopadhyay D, Riezman H (January 2007). "Proteasome-independent functions of ubiquitin in endocytosis and signaling". Science. 315 (5809): 2015. doi:10.1126/science.1127085. PMID 17218518.

52. Schnell JD, Hicke L (September 2003). "Non-traditional functions of ubiquitin and ubiquitinbinding proteins". The Journal of Biological Chemistry. 278 (38): 3585760. doi:10.1074/jbc.R300018200. PMID 12860974. 
